\title{
Antiproliferative Activity of Cinnamomum cassia Constituents and Effects of Pifithrin-Alpha on Their Apoptotic Signaling Pathways in Hep G2 Cells
}

\author{
Lean-Teik $\mathrm{Ng}^{1}$ and Shu-Jing $\mathrm{Wu}^{2}$ \\ ${ }^{1}$ Department of Agricultural Chemistry, National Taiwan University, No.1, Roosevelt Road Section 4, Taipei 106, Taiwan \\ ${ }^{2}$ Department of Nutritional Health, Chia-Nan University of Pharmacy and Science, 60, Erh-Jen Road, \\ Section 1, Jen-Te, Tainan 717, Taiwan
}

Correspondence should be addressed to Shu-Jing Wu,wsj268@mail.chna.edu.tw

Received 25 August 2009; Accepted 25 November 2009

Copyright ( 2011 L.-T. Ng and S.-J. Wu. This is an open access article distributed under the Creative Commons Attribution License, which permits unrestricted use, distribution, and reproduction in any medium, provided the original work is properly cited.

Cinnamaldehyde (Cin), cinnamic acid (Ca) and cinnamyl alcohol (Cal), major constituents of Cinnamomum cassia, have been shown to possess antioxidant, anti-inflammatory, anticancer and other activities. In this study, our aim was to evaluate the antiproliferative activity of these compounds in human hepatoma Hep G2 cells and examine the effects of pifithrin-alpha (PFT $\alpha$; a specific p53 inhibitor) on their apoptotic signaling transduction mechanism. The antiproliferative activity was measured by XTT assay. Expression of apoptosis-related proteins was detected by western blotting. Results showed that at a concentration of $30 \mu \mathrm{M}$, the order of antiproliferative activity in Hep G2 cells was Cin $>\mathrm{Ca}>\mathrm{Cal}$. Cin $\left(\mathrm{IC}_{50} 9.76 \pm 0.67 \mu \mathrm{M}\right)$ demonstrated an antiproliferative potency as good as 5-fluorouracil (an anti-cancer drug; $\mathrm{IC}_{50} 9.57 \pm 0.61 \mu \mathrm{M}$ ). Further studies on apoptotic mechanisms of Cin showed that it downregulated the expression of Bcl-xL, upregulated CD95 (APO-1), p53 and Bax proteins, as well as cleaving the poly (ADP-ribose) polymerase (PARP) in a time-dependent pattern. PFT $\alpha$ pre-incubation significantly diminished the effect of Cin-induced apoptosis. It markedly upregulated the anti-apoptotic $\left(\mathrm{Bcl}-\mathrm{xL}_{\mathrm{L}}\right)$ expression and downregulated the pro-apoptotic (Bax) expression, as well as effectively blocking the CD95 (APO-1) and p53 expression, and PARP cleavage in Cin-treated cells. This study indicates that Cin was the most potent antiproliferative constituent of C. cassia, and its apoptotic mechanism in Hep G2 cells could be mediated through the p53 induction and CD95 (APO-1) signaling pathways.

\section{Introduction}

Cinnamomum cassia Presl. (Lauraceae) has been traditionally used to treat dyspepsia, gastritis, blood circulation disturbances and inflammatory diseases [1]; it is an important ingredient in herbal preparations [2, 3]. Its major components cinnamaldehyde (Cin), cinnamic acid (Ca) and cinnamyl alcohol (Cal) were reported to have various biological activities. For example, Ca possessed antioxidant, anti-inflammatory and anticancer properties [4-6]. Cal is a fragrance ingredient, which is used in cosmetics, shampoos, soaps and other toiletries [7]. Cin exhibited antifungal, antipyretic, antioxidant, antimicrobial and larvicidal activities [8-10], as well as modulating Tcell differentiation [11]. In anticancer study, Cin was active against human liver, lung and leukemia cancer cells [12-14]. However, the antihepatoma activity and mechanism(s) of action of Cin, $\mathrm{Ca}$ and $\mathrm{Cal}$ in Hep G2 cells have never been investigated.

In our previous studies, p53 induction and MAPK pathways were shown to require for Cin-mediated apoptosis in PLC/PRF/5 cells [14]. In this study, we examined the anti-hepatoma activity of $C$. cassia bioactive components in Hep G2 cell lines. Hep G2 cells are highly differentiated cells [15], whereas PLC/PRF/5 is less divided but highly migrated hepatoma cells [16]. It functionally behaves as highly differentiated liver parenchymal cells and is karyologically distinguishable from PLC/PRF/5 due to the presence of trisomy 6 (pter leads to q14) and a long arm of chromosome $15 q+[15]$. Hep G2 not PLC/PRF/5 cells secrete IGF carrier protein [17] and produce $\alpha$-2-plasmin inhibitor $(\alpha-\mathrm{PI})$, a physiological inhibitor [18]. PLC/PRF/5 cells possess mutant or null p53 protein whereas Hep G2 cells have wild-type p53 protein $[14,19]$. 
Apoptosis is a process in which cell death is initiated and completed in an orderly manner through activation and/or synthesis of gene products necessary for cell destruction [20]. p53 directly activated the promoter of the CD95 (APO-1) gene in response to DNA damage by anticancer agents. The upregulation of the CD95 (APO-1) death receptor was only observed in cells with wild-type p53, but not in cells with mutant or null p53 [19]. Activation of p53 (a tumor suppressor protein) is known to result in the altered transcription of a wide variety of genes involving in-cell metabolism, cell cycle regulation and apoptosis [21, 22]. Both pro-apoptotic (Bax, Bak, Bid, Noxa, etc.) and anti-apoptotic (Bcl-2, Bcl-xL, $\mathrm{Mcl}-1, \mathrm{Bcl}-\mathrm{w}$, etc.) proteins have been reported to be key regulators of apoptosis [23]. Genes transcriptionally upregulated by p53 are implicated in promoting apoptosis, which includes the Bcl-2 family members (e.g., Bax, Bak) and Noxa gene proteins [2426]. The p53-dependent apoptotic pathway can lead to the cellular protein cleavage (e.g., PARP), DNA damage and cell death.

Pifithrin-alpha (PFT $\alpha$; a p53 inhibitor) is able to suppress p53-mediated transactivation [27]. It significantly decreased p53 expression on wild type p53 cells, but had no effect on mutant p53 cells or p53-deficient cells [28]. In this study, our aims were (i) to evaluate the antiproliferative activity of Cin, $\mathrm{Ca}$ and $\mathrm{Cal}$ in human hepatoma Hep G2 (CD95-positive) cells; (ii) to investigate the role of $\mathrm{p} 53, \mathrm{Bcl}-2$ family proteins (Bax and $\mathrm{Bcl}-\mathrm{xL}$ ) and PARP in Cin-mediated apoptosis; and (iii) to study the effects of PFT $\alpha$ on p53 and Bcl-2 family proteins, as well as PARP cleavage in Hep G2 cells.

\section{Methods}

2.1. Chemicals. Cin, $\mathrm{Ca}$ and Cal with purity greater than $98 \%$ were purchased from Merck Chemical Industries (Germany). Pifithrin-alpha $(\mathrm{PFT} \alpha)$ was purchased from Calibiochem (San Diego, CA, USA). Dulbecco's modified Eagle's medium (DMEM), dimethyl sulfoxide (DMSO), penicillin, streptomycin, aprotonin, trypsin-EDTA, sodium 3,3'-[1(phenylaminocarbonyl)-3,4-tetrazolium]-bis(4-methoxy-6nitro) benzene sulfonic acid (XTT), 5-flurouracil (5FU) and anti- $\beta$-actin body were purchased from Sigma Chemical Co. (St. Louis, MO, USA). Fetal bovine serum (FBS) was obtained from GIBCO BRL (Gaithersburg, MD, USA). The anti-Bax, anti-Bcl-xL, anti-CD95 (APO-1/CD95), anti-p53, anti-PARP, anti-rabbit IgG and anti-mouse IgG bodies were purchased from PharMingen (San Diego, CA, USA).

2.2. Preparation of Cell Culture and Test Solutions. The human hepatoma Hep G2 cells (ATCC HB-8065) were obtained from the American Type Culture Collection (Rockville, MD, USA). They were grown in DMEM supplemented with $10 \%$ FBS, 100 units $\mathrm{mL}^{-1}$ penicillin and $100 \mu \mathrm{g} \mathrm{mL}^{-1}$ streptomycin at $37^{\circ} \mathrm{C}$ in a humidified atmosphere of $5 \% \mathrm{CO}_{2}$. All stock solutions were prepared in DMSO at a concentration of $10 \mathrm{mM}$ and stored at $-20^{\circ} \mathrm{C}$ until use. The concentrations of test compounds used for this study were $1,10,30,50$ and $70 \mu \mathrm{M}$, which were freshly prepared for each experiment with a final DMSO concentration of $0.1 \%$. Control samples were always treated with the same amount of DMSO $(0.1 \% \mathrm{v} / \mathrm{v})$ as used in the corresponding experiments.

2.3. Analysis of Antiproliferative Activity. Cells were seeded at a density of $1 \times 10^{5}$ cells per well on 12 -well plates. They were then treated with various concentrations of $\mathrm{Cin}, \mathrm{Ca}$, Cal or $0.1 \%$ DMSO (control) for 0, 6, 12 and $24 \mathrm{~h}$. After treatments, cells were washed once before adding $100 \mu \mathrm{L}$ of FBS-free medium containing XTT, followed by incubating at $37^{\circ} \mathrm{C}$ for $4 \mathrm{~h}$. The absorbance of samples was measured with an ELISA reader (Bio-Rad, USA) at a test wavelength of $492 \mathrm{~nm}$ and a reference wavelength of $690 \mathrm{~nm}$.

2.4. Pifithrin-alpha (PFT $\alpha$; A p53 Inhibitor) Treatment. Cells were assured to grow normally before inhibitor treatment. Confluent cells in each experiment were pretreated for $1 \mathrm{~h}$ with $30 \mu \mathrm{M}$ PFT $\alpha$ dissolving in DMSO. The cells were treated with $30 \mu \mathrm{M}$ Cin or $0.1 \%$ DMSO (control) for $24 \mathrm{~h}$ and then harvested for apoptotic assays. The inhibitor was prepared according to the manufacturer's instructions. In all experiments, the vehicle used to prepare stock solutions was noted to have no effect on the cell viability.

2.5. Analysis of PFT $\alpha$ Effects on Cin-Induced Apoptosis. Cells were seeded at a density of $1 \times 10^{5}$ cells per well onto 12 well plates. They were treated with $0.1 \%$ DMSO (control) or $30 \mu \mathrm{M}$ Cin only or pretreated with $30 \mu \mathrm{M}$ PFT $\alpha$ for $1 \mathrm{~h}$ before adding $30 \mu \mathrm{M}$ Cin. After $24 \mathrm{~h}$ of treatment, cells were washed once before adding $100 \mu \mathrm{L}$ of FBS-free medium containing XTT. After $4 \mathrm{~h}$ of incubation at $37^{\circ} \mathrm{C}$, the absorbance of samples was measured with an ELISA reader.

\section{Western Immunoblot Analysis}

Cells were harvested and subjected to procedures described previously [14]. The specific primary antibodies used in this study were anti-Bax $(1: 250)$, anti-Bcl-XL $(1: 500)$, antiCD95/APO-1 (1:5000), anti-p53 (1:500) and anti-PARP $(1: 500)$ antibodies.

3.1. Statistical Analysis. Values were evaluated by one-way ANOVA, followed by Duncan's multiple range tests using the Statistical Analysis System (SAS Institute, Cary, NC, USA). Differences were considered significant when the $P$-value was $<.05$.

\section{Results}

4.1. Antiproliferative Activity of Cin, $\mathrm{Ca}$ and Cal in Hep G2 Cells. To examine the antiproliferative effect of Cin, $\mathrm{Ca}$ and Cal on Hep G2 cells, cells were treated with different concentrations of these compounds using XTT assay. Results showed that all test compounds exhibited inhibitory effects on the growth of Hep G2 cells, with an $\mathrm{IC}_{50}$ value of $9.76 \pm$ $0.67 \mu \mathrm{M}$ for Cin, $34.20 \pm 0.99 \mu \mathrm{M}$ for $\mathrm{Ca}$ and $58.30 \pm 1.49 \mu \mathrm{M}$ for Cal (Figure 1). The potency of Cin was closed to that of 


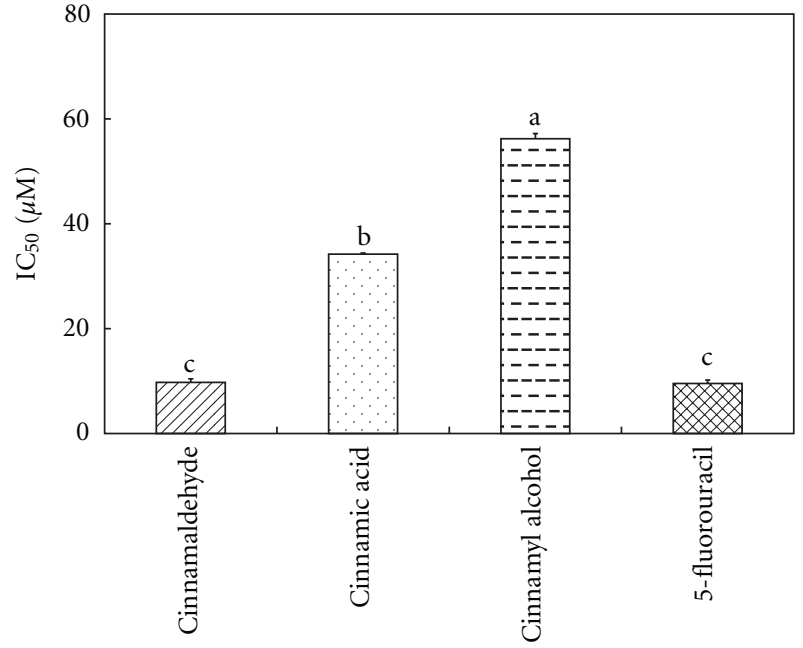

FIGURE 1: IC $_{50}$ values of antiproliferative activity of cinnamaldehyde, cinnamic acid and cinnamyl alcohol. The data shown are means \pm SD of three independent experiments. Bars with different alphabetical letters were significantly different at $P<.05$.

the positive control $5 \mathrm{FU}\left(\mathrm{IC}_{50} 9.57 \pm 0.61 \mu \mathrm{M}\right)$. Hence, it was selected for detailed study of apoptotic mechanism.

4.2. Inhibition of Cell Proliferation by Cin. As shown in Table 1, Cin inhibited the proliferation of Hep G2 cells in a dose- and time-dependent manner. Compared with the control, Cin at $30 \mu \mathrm{M}$ caused a nearly $71 \%$ inhibition of cell growth as demonstrated by a significant increase in the number of apoptotic cells. This concentration of Cin was used in all further experiments.

4.3. CD95 (APO-1/CD95) Is Involved in Cin-Induced Apoptosis. CD95 (APO-1/CD95) pathway has been well documented to participate in certain anticancer drugs-induced apoptosis. In this study, results showed that Cin caused a time-dependent increase in the CD95 (APO-1/CD95) protein expression in Hep G2 cells (Figure 2).

4.4. Cin Treatment Downregulates $B c$ - $_{X L}$ and Upregulates Bax and 553 Protein Levels. Treatment with $30 \mu \mathrm{M}$ Cin resulted in the downregulation of the anti-apoptotic $(\mathrm{Bcl}-\mathrm{xL})$ and the upregulation of the pro-apoptotic (Bax) proteins in a time-dependent fashion (Figure 2). The expression of $\mathrm{Bcl}-\mathrm{xL}$ protein was noted to disappear after $24 \mathrm{~h}$ of Cin treatment. As expected, Cin did cause an increase in the level of p53 as Hep G2 cells contain wild-type p53.

4.5. Cin-Induced Apoptosis Exhibits PARP Cleavage. To further confirm the Cin-induced apoptosis, cells were treated with Cin for 0, 6, 12 and $24 \mathrm{~h}$. PARP cleavage was determined by immunoblotting analysis. Results showed that PARP proform (molecular mass, $116 \mathrm{kDa}$ ) was cleaved to give an $85 \mathrm{kDa}$ fragment in Cin-treated cells at 12 and $24 \mathrm{~h}$ after treatment (Figure 2).

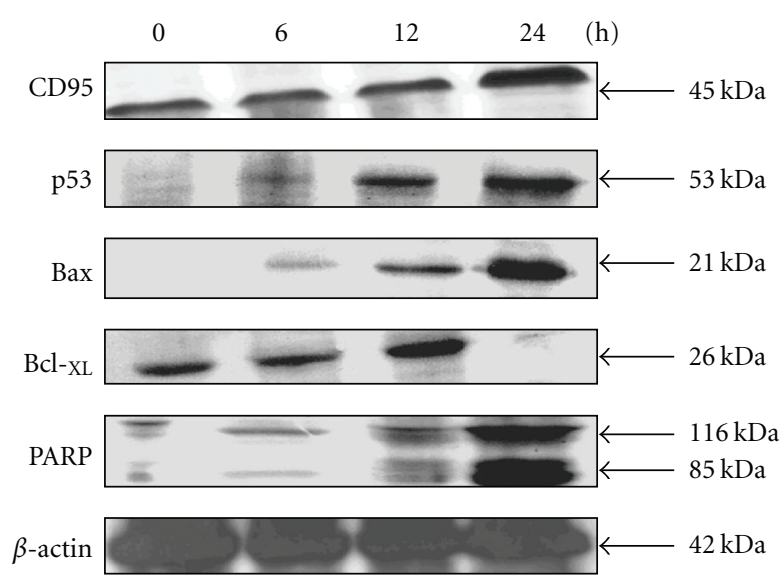

FIgURE 2: Effects of apoptotic signal transduction factors (CD95, p53, Bax, Bcl-xL and PARP) in Cin-induced cell death. Cells were treated with $30 \mu \mathrm{M}$ Cin for $0,6,12$ and $24 \mathrm{~h}$ and then harvested for Western blotting analysis. $\beta$-Actin was used as a positive control.

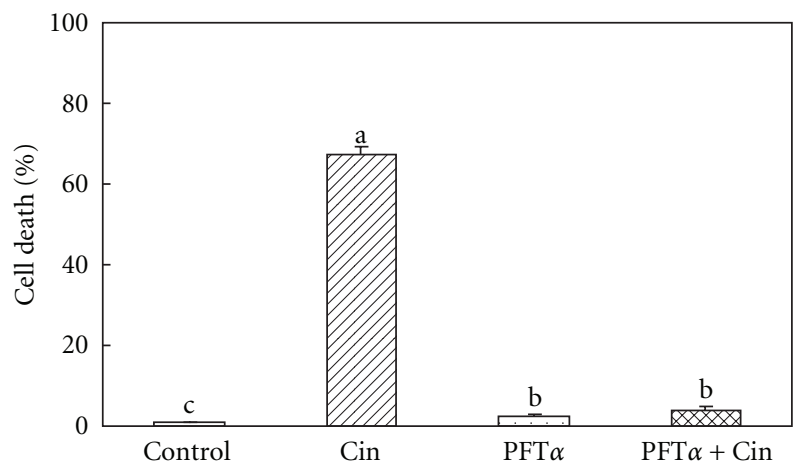

FIGURE 3: Effects of the p53 inhibitor (PFT $\alpha$ ) on Cin-induced cell death. The data represent means \pm SD of three independent experiments. Bars with different alphabetical letters were significantly different at $P<.05$.

4.6. Pifithrin $\alpha$ (PFT $\alpha)$ Prevents the Cin-Induced Apoptosis. To determine whether the Cin induction of apoptosis was affected by the presence of $30 \mu \mathrm{M}$ PFT $\alpha$, Hep G2 cells were pre-incubated with PFT $\alpha$ for $1 \mathrm{~h}$, and then induced to undergo apoptosis by treatment with Cin. Results showed that PFT $\alpha$ significantly $(P<.05)$ inhibited the Cin-induced Hep G2 cell death (Figure 3).

4.7. PFTa Suppresses the Expression of CD95 (APO-1/CD95), p53 and Bax Proteins. To evaluate the relative role of CD95 (APO-1/CD95), p53, Bcl-2 family (Bax, Bcl-xL) proteins and PARP cleavage in the Cin-induced apoptotic events, cells were pretreated with PFT $\alpha$. Results displayed that pre-incubation the Hep G2 cells with $30 \mu \mathrm{M}$ PFT $\alpha$ alone and $30 \mu \mathrm{M}$ PFT $\alpha+30 \mu \mathrm{M}$ Cin effectively inhibited the expression of Bax, p53 and CD95, as well as the cleavage of PARP (Figure 4). These pretreatment also prevented the downregulation of $\mathrm{Bcl}-\mathrm{xL}$ in cells. 
TABLE 1: Effects of Cin-induced apoptosis on human Hep G2 cells.

\begin{tabular}{|c|c|c|c|c|}
\hline \multirow{2}{*}{ Cin treatment $(\mu \mathrm{M})$} & \multicolumn{4}{|c|}{ Apoptotic cells (\%) } \\
\hline & $0 \mathrm{~h}$ & $6 \mathrm{~h}$ & $12 \mathrm{~h}$ & $24 \mathrm{~h}$ \\
\hline 0 & $0.10 \pm 0.00^{c}$ & $0.10 \pm 0.08^{\mathrm{d}}$ & $0.10 \pm 0.08^{\mathrm{d}}$ & $0.13 \pm 0.05^{\mathrm{d}}$ \\
\hline 1 & $0.50 \pm 0.16^{\mathrm{c}}$ & $8.25 \pm 0.94^{c}$ & $17.07 \pm 0.74^{c}$ & $41.13 \pm 0.74^{\mathrm{c}}$ \\
\hline 10 & $5.00 \pm 0.82^{\mathrm{b}}$ & $13.20 \pm 0.80^{\mathrm{b}}$ & $45.96 \pm 0.23^{\mathrm{b}}$ & $50.10 \pm 0.70^{\mathrm{b}}$ \\
\hline 30 & $16.98 \pm 0.14^{\mathrm{a}}$ & $38.67 \pm 2.49^{a}$ & $60.32 \pm 0.50^{\mathrm{a}}$ & $70.73 \pm 3.03^{\mathrm{a}}$ \\
\hline
\end{tabular}

After treatment, cell numbers were estimated by the XTT assay. Data are presented as means \pm SD of three independent experiments. Values within the column with different superscript letters were significant at $P<.05$.

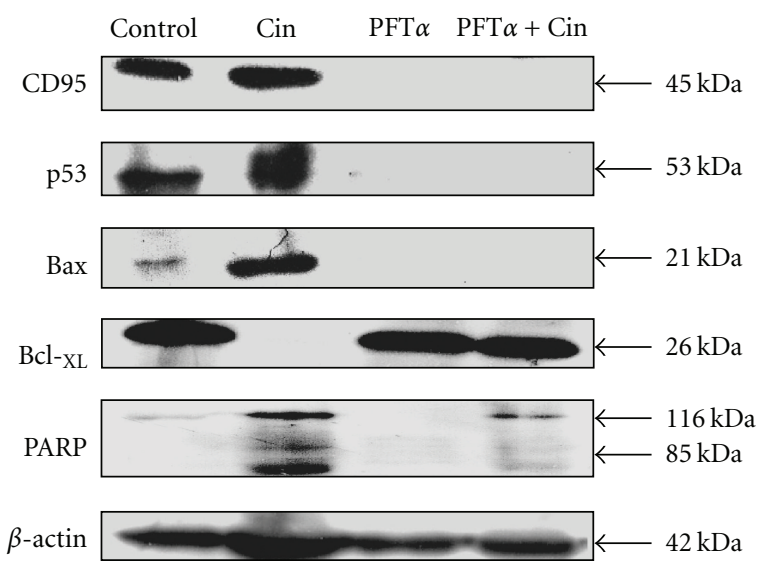

FIGURE 4: Effects of p53 inhibitor (PFT $\alpha)$ on Cin-induced apoptosis. Hep G2 cells were treated without or with $30 \mu \mathrm{M}$ PFT $\alpha$ for $1 \mathrm{~h}$, and then in the presence or absence of $30 \mu \mathrm{M}$ Cin for $24 \mathrm{~h}$. The total cell lysate was then analyzed by western blotting analysis. $\beta$-Actin was used as a positive control.

\section{Discussion}

We have demonstrated that the major components of C. cassia, that is, Cin, $\mathrm{Ca}$ and $\mathrm{Cal}$ possessed a different magnitude of antiproliferative effect on human hepatoma Hep G2 cells. Among them, Cin was the most potent compound, which exhibited an $\mathrm{IC}_{50}$ value closed to that of the commercial anticancer agent 5 FU.

Cin has been shown to possess antitumor activity through inhibiting cell proliferation and inducing cell apoptosis [29-31]. Its inhibitory effect on cell cycle progression was demonstrated to be through the arrest of the $S$ phase in human PLC/PRF/5 cells [31]. In this study, the effect of Cin on Hep G2 cell apoptosis was noted to be on the CD95 (APO-1/CD95) signal transduction and p53 pathways. It was also found that pretreatment with a p53 inhibitor (PFT $\alpha)$ could block the process of programmed cell death and prevent the apoptotic signal transduction pathway.

Several studies have shown that the Bcl-2 family of proteins is the central of apoptotic regulation [32, 33]. Overexpression of $\mathrm{Bcl}-2$ and $\mathrm{Bcl}-\mathrm{XL}$ aborts the apoptotic response while Bax, Bid and Bak activity promotes cell death [32]. Our results displayed that Cin activated wild-type p53 and caused an up-expression of Bax as well as triggering the down-expression of $\mathrm{Bcl}-\mathrm{xL}$ with a subsequent promotion of

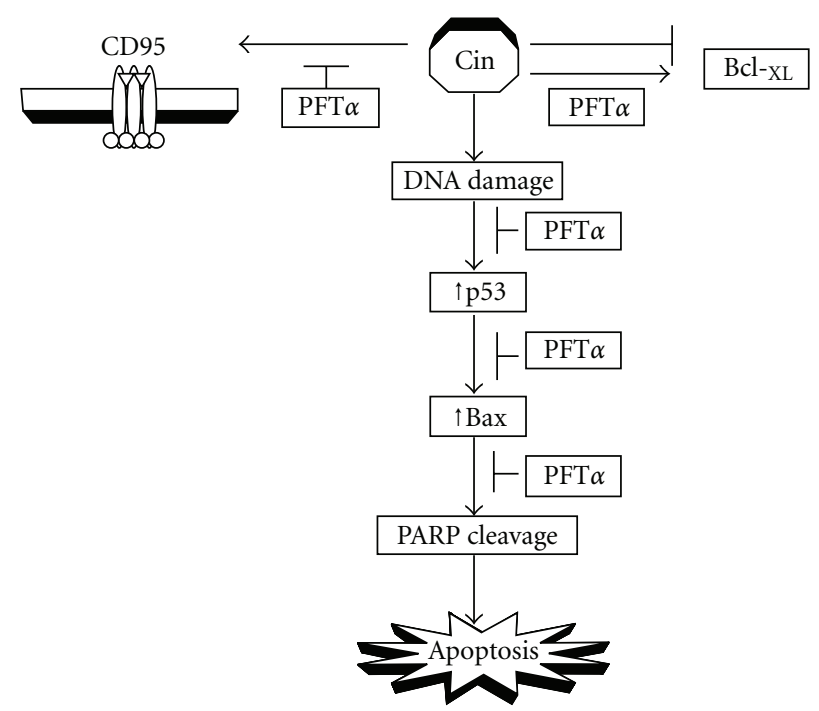

Figure 5: The mode of action of PFT $\alpha$ on the Cin-mediated apoptosis in Hep G2 cells.

the apoptotic activity in Hep G2 cells. p53 has been reported to mediate Bax upregulation [25]. It is possible that the Cinmediated activation of Bax triggers the cleavage of PARP and lead to a p53-dependent pathway. The apoptotic induction in wild-type p53 cells has also been noted on taiwanin A and gambogic acid $[34,35]$.

PFT $\alpha$, a small molecule identified as an inhibitor of p53 transcriptional activity, has been shown to protect against the toxic side effects of anticancer treatment to the normal tissues [36, 37]. It may also interfere with the apoptosis of tumor cells that sense DNA damage in response to genotoxic stress [38]. In this study, PFT $\alpha$ was able to completely inhibit the modulation of CD95 (APO-1/CD95), p53 and Bax proteins, and the suppression of the PARP cleavage in Cintreated cells. This indicates that PFT $\alpha$ significantly prevented Cin-mediated apoptosis through blocking the expression of apoptotic signal factors such as CD95 (APO-1/CD95), Bax, p53 and PARP degradation in Hep G2 cells (Figure 5).

\section{Conclusion}

Among the major components of C. cassia, Cin has demonstrated to possess the most potent antiproliferative activity in Hep G2 cells. It was the first study to demonstrate the role of 
CD95 (APO-1/CD95) and p53 in the Cin-induced apoptotic signaling. In addition, PFT $\alpha$ was found to markedly block the Cin-induced apoptosis through upregulating the antiapoptotic $(\mathrm{Bcl}-\mathrm{xL})$ and downregulating the pro-apoptotic (Bax) proteins, as well as suppressing the PARP cleavage. Importantly, PFT $\alpha$ completely attenuated the activation of CD95 (APO-1/CD95) and p53 in Cin-treated cells. These results suggest that the modulation of apoptotic pathways through the CD95 (APO-1/CD95), p53, PARP cleavage and Bcl-2 family proteins signaling transductions could be an important therapeutic goal in the prevention and treatment of cancer.

\section{Acknowledgment}

The authors would like to thank Chia Nan University of Pharmacy and Science for partial funding of this study.

\section{References}

[1] Z. Q. Lou and B. Qin, Species Systematization and Quality Evaluation of Commonly Used Chinese Traditional Drugs, vol. 1, Beijing University Medical Press, Beijing, China, 1995.

[2] Z. Shijie, J. Moriya, J. Yamakawa, R. Chen, T. Takahashi, and H. Sumino, "Mao-to prolongs the survival of and reduces TNF$\alpha$ expression in mice with viral myocarditis," Evidence-Based Complementary and Alternative Medicine, 2008.

[3] F. P. Chen, M. S. Jong, Y. C. Chen, Y. Y. Kung, T. J. Chen, and F. J. Chen, "Prescriptions of Chinese herbal medicines for insomnia in Taiwan during 2002," EvidenceBased Complementary and Alternative Medicine, 2009.

[4] L. P. Zhang and Z. Z. Ji, "Synthesis, antiinflammatory and anticancer activity of cinnamic acids, their derivatives and analogues," Yao Xue Xue Bao, vol. 27, pp. 817-823, 1992.

[5] Y. Akao, H. Maruyama, K. Matsumoto et al., "Cell growth inhibitory effect of cinnamic acid derivatives from propolis on human tumor cell lines," Biological and Pharmaceutical Bulletin, vol. 26, no. 7, pp. 1057-1059, 2003.

[6] M. C. Foti, C. Daquino, and C. Geraci, "Electron-transfer reaction of cinnamic acids and their methyl esters with the $\mathrm{DPPH}^{\bullet}$ radical in alcoholic solutions," The Journal of Organic Chemistry, vol. 69, pp. 2309-1214, 2004.

[7] C. S. Letizia, J. Cocchiara, J. Lalko, A. Lapczynski, and A. M. Api, "Fragrance material review on cinnamyl alcohol," Food and Chemical Toxicology, vol. 43, no. 6, pp. 837-866, 2005.

[8] C.-C. Lin, S.-J. Wu, C.-H. Chang, and L.-T. Ng, "Antioxidant activity of Cinnamomum cassia," Phytotherapy Research, vol. 17, no. 7, pp. 726-730, 2003.

[9] S. S. Cheng, J. Y. Liu, K. H. Tsai, W. J. Chen, and S. T. Chang, "Chemical composition and mosquito larvicidal activity of essential oils from leaves of different Cinnmomum osmophloeum provenances," Journal of Agricultural and Food Chemistry, vol. 52, pp. 4395-4400, 2004.

[10] H.-O. Kim, S.-W. Park, and H.-D. Park, "Inactivation of Escherichia coli O157:H7 by cinnamic aldehyde purified from Cinnamomum cassia shoot," Food Microbiology, vol. 21, no. 1, pp. 105-110, 2004.

[11] W. S. Koh, S. Y. Yoon, B. M. Kwon, T. C. Jeong, K. S. Nam, and M. Y. Han, "Cinnamaldehyde inhibits lymphocyte proliferation and modulates T-cell differentiation," International Journal of Immunopharmacology, vol. 20, no. 11, pp. 643-660, 1998.
[12] K. H. Moon and M. Y. Pack, "Cytotoxicity of cinnamic aldehyde on leukemia L1210 cells," Drug and Chemical Toxicology, vol. 6, no. 6, pp. 521-535, 1983.

[13] T. Imai, K. Yasuhara, T. Tamura et al., "Inhibitory effects of cinnamaldehyde on 4-(methylnitrosamino)-1-(3-pyridyl)-1butanone-induced lung carcinogenesis in rasH2 mice," Cancer Letters, vol. 175, no. 1, pp. 9-16, 2002.

[14] S.-J. Wu and L.-T. Ng, "MAPK inhibitors and pifithrinalpha block cinnamaldehyde-induced apoptosis in human PLC/PRF/5 cells," Food and Chemical Toxicology, vol. 45, no. 12, pp. 2446-2453, 2007.

[15] D. Simon, D. P. Aden, and B. B. Knowles, "Chromosomes of human hepatoma cell lines," International Journal of Cancer, vol. 30, no. 1, pp. 27-33, 1982.

[16] I. Zvibel, E. Halay, and L. M. Reid, "Heparin and hormonal regulation of mRNA synthesis and abundance of autocrine growth factors: relevance to clonal growth of tumors," Molecular and Cellular Biology, vol. 11, no. 1, pp. 108-116, 1991.

[17] A. C. Moses, A. J. Freinkel, B. B. Knowles, and D. P. Aden, "Demonstration that a human hepatoma cell line produces a specific insulin-like growth factor carrier protein," Journal of Clinical Endocrinology and Metabolism, vol. 56, no. 5, pp. 1003-1008, 1983.

[18] H. Saito, L. T. Goodnough, B. B. Knowles, and D. P. Aden, "Synthesis and secretion of alpha 2-plasmin inhibitor by established human liver cell lines," Proceedings of the National Academy of Sciences of the United States of America, vol. 79, pp. 5684-5687, 1982.

[19] M. Muller, S. Wilder, D. Bannasch et al., "p53 activates the CD95 (APO-1/Fas) gene in response to DNA damage by anticancer drugs," Journal of Experimental Medicine, vol. 188, no. 11, pp. 2033-2045, 1998.

[20] J. Huang, L. Wu, S. I. Tashiro, S. Onodera, and T. Ikejima, "Reactive oxygen species mediated oridonin-induced Hep G2 apoptosis through p53, MAPK, and mitochondrial signaling pathways," Journal of Pharmacological Sciences, vol. 107, pp. 370-379, 2008.

[21] Y.-J. Lee, H.-C. Kuo, C.-Y. Chu, C.-J. Wang, W.-C. Lin, and T.$\mathrm{H}$. Tseng, "Involvement of tumor suppressor protein p53 and p38 MAPK in caffeic acid phenethyl ester-induced apoptosis of C6 glioma cells," Biochemical Pharmacology, vol. 66, no. 12, pp. 2281-2289, 2003.

[22] J. Bai and A. I. Cederbaum, "Cycloheximide protects HepG2 cells from serum withdrawal-induced apoptosis by decreasing p53 and phosphorylated p53 levels," Journal of Pharmacology and Experimental Therapeutics, vol. 319, no. 3, pp. 1435-1443, 2006.

[23] J. M. Adams and S. Cory, "The Bcl-2 protein family: arbiters of cell survival," Science, vol. 281, no. 5381, pp. 1322-1326, 1998.

[24] S. Fulda, E. Meyer, and K.-M. Debatin, "Metabolic inhibitors sensitize for CD95 (APO-1/Fas)-induced apoptosis by downregulating Fas-associated death domain-like interleukin 1converting enzyme inhibitory protein expression," Cancer Research, vol. 60, no. 14, pp. 3947-3956, 2000.

[25] N. O. Karpinich, M. Tafani, R. J. Rothman, M. A. Russo, and J. L. Farber, "The course of etoposide-induced apoptosis from damage to DNA and p53 activation to mitochondrial release of cytochrome c," The Journal of Biological Chemistry, vol. 277, pp. 16547-16552, 2002.

[26] C. Borner, "The Bcl-2 protein family: sensors and checkpoints for life-or-death decisions," Molecular Immunology, vol. 39, no. 11, pp. 615-647, 2003.

[27] P. G. Komarov, E. A. Komarova, R. V. Kondratov et al., "A chemical inhibitor of $\mathrm{p} 53$ that protects mice from the side 
effects of cancer therapy," Science, vol. 285, no. 5434, pp. 17331737, 1999.

[28] J. F. Charlot, M. Nicolier, J. L. Prétet, and C. Mougin, "Modulation of p53 transcriptional activity by PRIMA-1 and Pifithrin- $\alpha$ on staurosporine-induced apoptosis of wild-type and mutated p53 epithelial cells," Apoptosis, vol. 11, no. 5, pp. 813-827, 2006.

[29] B.-M. Kwon, S.-H. Lee, S. U. Choi et al., "Synthesis and in vitro cytotoxicity of cinnamaldehydes to human solid tumor cells," Archives of Pharmacal Research, vol. 21, no. 2, pp. 147-152, 1998.

[30] S.-J. Wu, L.-T. Ng, and C.-C. Lin, "Effects of vitamin E on the cinnamaldehyde-induced apoptotic mechanism in human PLC/PRF/5 cells," Clinical and Experimental Pharmacology and Physiology, vol. 31, no. 11, pp. 770-776, 2004.

[31] S.-J. Wu, L.-T. Ng, and C.-C. Lin, "Cinnamaldehyde-induced apoptosis in human PLC/PRF/5 cells through activation of the proapoptotic Bcl-2 family proteins and MAPK pathway," Life Sciences, vol. 77, no. 8, pp. 938-951, 2005.

[32] S. Cory and J. M. Adams, "The BCL2 family: regulators of the cellular life-or-death switch," Nature Reviews Cancer, vol. 2, no. 9, pp. 647-656, 2002.

[33] W. Yu, B. G. Sanders, and K. Kline, "RRR- $\alpha$-tocopheryl succinate-induced apoptosis of human breast cancer cells involves bax translocation to mitochondrial," Cancer Research, vol. 63, no. 10, pp. 2483-2491, 2003.

[34] P.-J. Ho, C.-K. Chou, Y.-H. Kuo, L.-C. Tu, and S.-F. Yeh, "Taiwanin A induced cell cycle arrest and p53-dependent apoptosis in human hepatocellular carcinoma HepG2 cells," Life Sciences, vol. 80, no. 5, pp. 493-503, 2007.

[35] H. Gu, X. Wang, S. Rao, J. Wang, J. Zhao, and F. L. Ren, "Gambogic acid mediates apoptosis as a p53 inducer through down-regulation of $\mathrm{mdm} 2$ in wild-type $\mathrm{p} 53$-expressing cancer cells," Molecular Cancer Therapeutics, vol. 10, pp. 3298-3305, 2008.

[36] E. A. Komarova and A. V. Gudkov, "Suppression of p53: a new approach to overcome side effects of antitumor therapy," Biochemistry, vol. 65, no. 1, pp. 41-48, 2000.

[37] E. A. Komarova and A. V. Gudkov, "Chemoprotection from p53-dependent apoptosis: potential clinical applications of the p53 inhibitors," Biochemical Pharmacology, vol. 62, no. 6, pp. 657-667, 2001.

[38] E. Lorenzo, C. Ruiz-Ruiz, A. J. Quesada et al., "Doxorubicin induces apoptosis and CD95 gene expression in human primary endothelial cells through a p53-dependent mechanism," Journal of Biological Chemistry, vol. 277, no. 13, pp. 1088310892, 2002. 


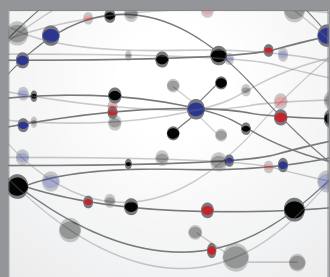

The Scientific World Journal
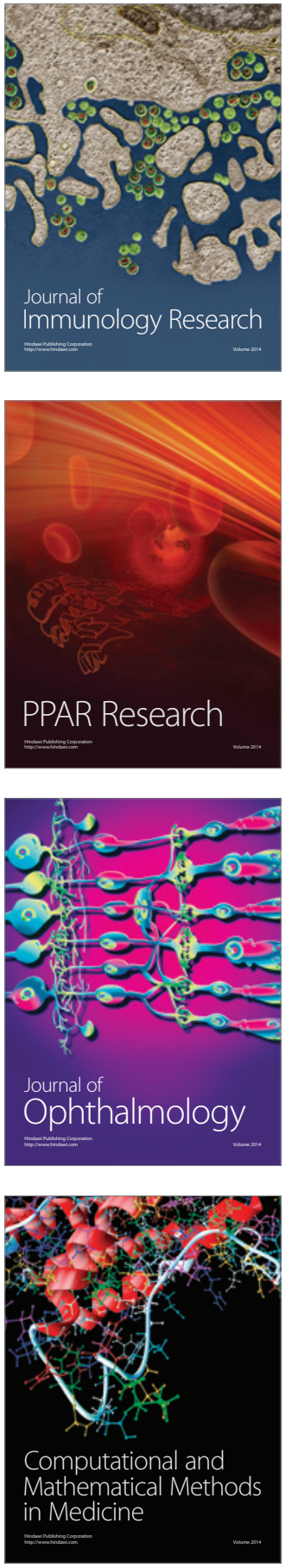

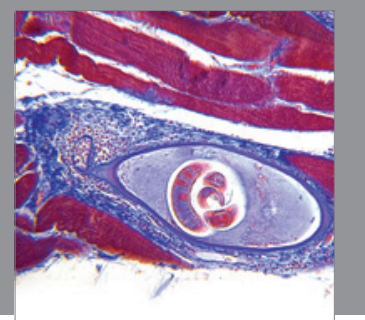

Gastroenterology

Research and Practice
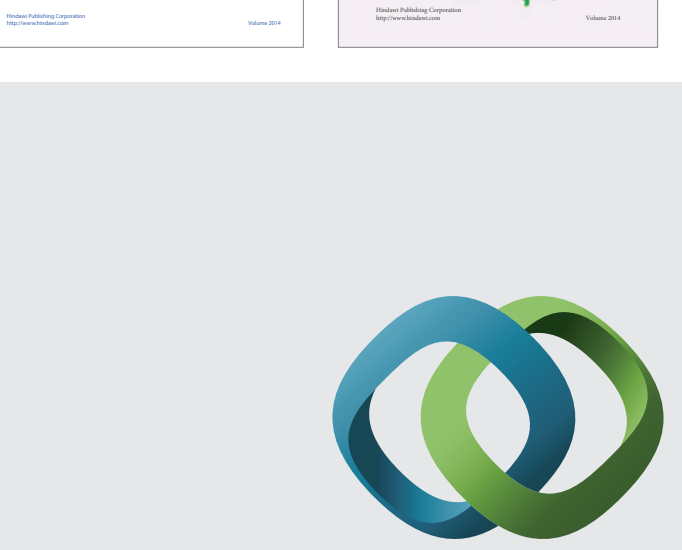

\section{Hindawi}

Submit your manuscripts at

http://www.hindawi.com
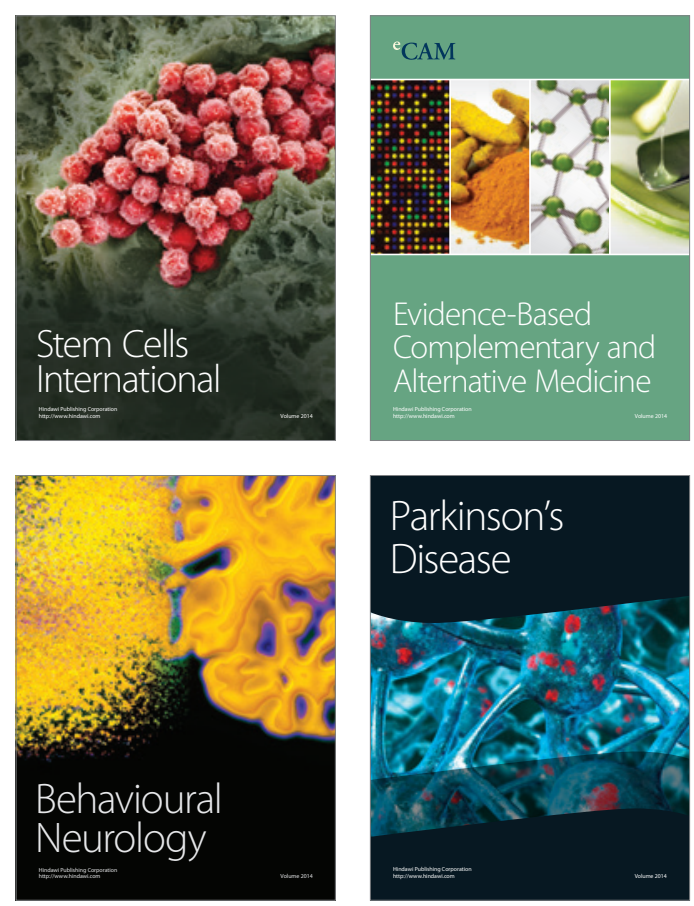

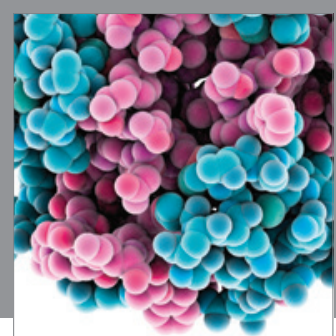

Journal of
Diabetes Research

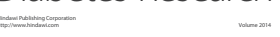

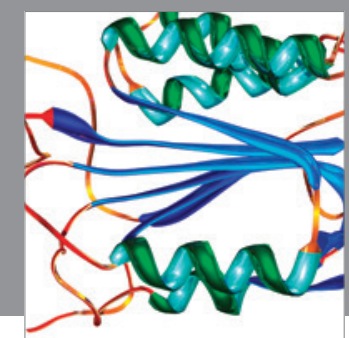

Disease Markers
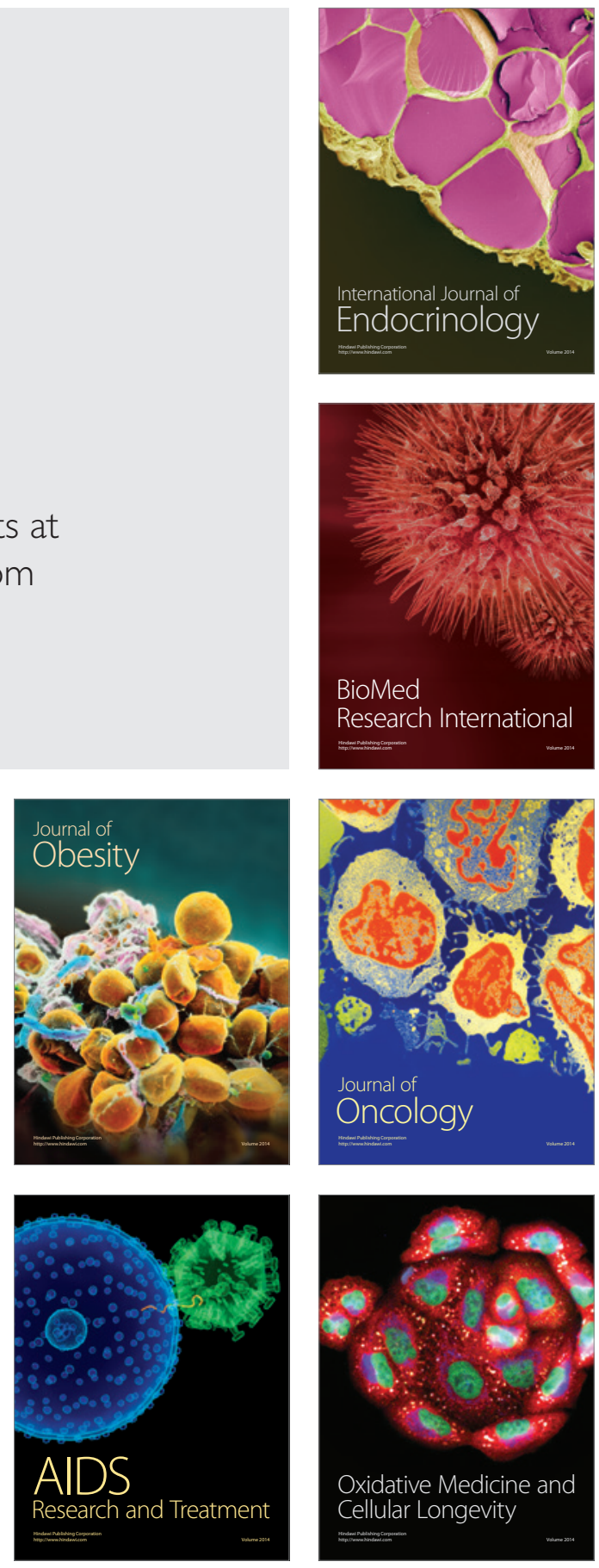